\title{
Career Maturity of Guidance and Counseling Students at The Yogyakarta State University
}

\author{
F.R Bahrinsyah \\ Universitas Negeri Yogyakarta \\ Yogyakarta, Indonesia
}

\begin{abstract}
The study aims to map the maturity of career guidance and counseling students which includes self-appraisal ability, work information, goal selection ability, planning ability, and skill in solving problems related to career development tasks. In approach, it used the explorative-descriptive research model. Involved as research subjects were students of the Graduate Study Program of Guidance and Counseling, Faculty of Education, Yogyakarta State University (YSU). The conclusions that could be drawn are as follows: 1). the career maturity level of guidance and counseling students is moderate in category (since $M=72.42$ ), with the students included in the moderate category being $69.3 \%, 2$ ). The great percentage in "the middle category" is a group which is quite vulnerable in experiencing instability in career maturity if not well intervened/facilitated, and 3). there is no significant difference in career maturity among students' batches of different years entrance (since $\mathbf{F}=\mathbf{0 . 8 5 5}$ with Sig. $=0.427$ ).
\end{abstract}

Keywords- Career Maturity; Guidance and Counseling Students;

\section{INTRODUCTION}

One of the theoretical concepts that most frequently used to evaluate an individual's readiness in entering the world of work is career maturity [11, 12]. It is an essential factor for career preparedness in the twenty-first century [3]. Career is not something that goes into process suddenly or runs by itself for it is, instead, a picture of the future that uses as constructs one's past achievements and lifelong competence development [5].

The process of career decision making would also be faced with global challenges like technological and informational progress, demographical changes, and competition in the global market. Therefore, the strategy in career service and education at the educational institution should be able to consider the various influencing factors that previously mentioned [5].

Super (Brown, 2007) identifies career maturity as a set of physical, psychological, and social characteristics that representing an individual's readiness and competence in facing and overcoming the career development problems and challenges that the individual concerned is being confronted with [2]. Such readiness and competence of the individual would determine the future success concerned. The appearance of the term career maturity is inseparable from Donald Super's interest in describing the individual's behavior pattern and choice in relation with the matters of career and work. Super described that career maturity refers to one's development towards self-efficacy. According to Super [4], career maturity which is inseparable from career choice preference is an ever-unfolding process and it is not a-pointin-time event. Therefore, career maturity could be viewed as an individual's ability to execute a set of developmental tasks within a certain age period. According to a frame of work developed by Super, career maturity signified by right choice is greatly influenced by work knowledge, self-concept understanding, and comprehension of how to make a decision.

In result of a further development, the career maturity concept is elaborated into the several following components [6]:

a. Self-appraisal ability, which is the individual's ability to map the actual condition of the individual's in terms of aptitude, interest, and personality characteristics,

b. Work information, which is related to the individual's ability in comprehending task and obligation descriptions fitting a certain work type,

c. Goal selection, which is related to the individual's ability in identifying the type of work which is the right one for the picture that the individual has,

d. Planning, which is related to the individual's ability in accurately making the right plan, and

e. Problem solving, which is related to the individual's skill in solving problems in relation with career development tasks.

The developments in the career maturity concept these days have gone to the extent of seeing the maturity not only from the point of technical-natured preference; self-concept; and work environment but also from the point of factors in the sociocultural environment and the context of the individual's achievement of psychological developmental tasks. Experts in this field explain that to take a picture of the individual's career maturity level, the reciprocal relation between the social developmental context and the personal self needs to be 
viewed. It means that the social context is important for the individual's development and the individual also has an important influence on the development of the social context [4].

Therefore, the career maturity mapping of guidance and counseling students is considered of utmost importance to do $[8,9]$. The study aims to map the maturity of career guidance and counseling students which includes self-appraisal ability, work information, goal selection ability, planning ability, and skill in solving problems related to career development tasks $[13,14,15]$.

\section{METHOD}

In the research concerned here, the explorative-descriptive research model was used [10]. The research subjects were undergraduate students of Guidance and Counseling at Yogyakarta State University.

By means of stratified random sampling, from the population of the students in the Graduate Study Program of Guidance and Counseling entering the university concerned in 2015, 2014, and 2013 numbering 240 in all, a sample of 150 students (with the number determined through the following calculation: 25 students $\mathrm{x} 6$ classes $=150$ ) was taken by using the Slovin formula. The profile of the sample taken is as shown in Table 1 as follows.

TABLE I. PROFILE OF STUdENTS' SAMPLE ACCORDING TO YEAR OF ENTRANCE (STUDENT BATCH) AND GENER TYPE

\begin{tabular}{rrrr}
\hline \multirow{2}{*}{ Year } & \multicolumn{2}{c}{ Gender Type } & \multicolumn{2}{c}{ Total } \\
\cline { 2 - 4 } & \multicolumn{2}{c}{ Male } & \multicolumn{2}{c}{ Female } & \multicolumn{2}{l}{5} \\
\cline { 2 - 4 } 2013 & 9 & $27.3 \%$ & $33.3 \%$ \\
\hline \multirow{2}{*}{2014} & $6.0 \%$ & 43 & 50 \\
\cline { 2 - 4 } & 7 & $28.7 \%$ & $33.3 \%$ \\
\hline \multirow{2}{*}{2015} & $4.7 \%$ & 45 & 50 \\
\cline { 2 - 4 } & $3.3 \%$ & $30.0 \%$ & $33.3 \%$ \\
\hline \multirow{2}{*}{ Total } & 21 & 129 & 150 \\
\cline { 2 - 4 } & $12.0 \%$ & $86.0 \%$ & $100 \%$ \\
\hline
\end{tabular}

The data used to reveal the guidance and counseling student's career maturity profile were obtained through a questionnaire with closed items 25 in number. The scores (and their interpretations) used in the questionnaire were 4 (Very Appropriate), 3 (Appropriate), 2 (Not So Appropriate), dan 1 (Not Appropriate), with the scores for items using the unfavorable form being ordered in reverse.

The data collecting method used in the research was the psychological scale method. The scale developed was of career maturity, whose aspects were self-appraisal ability, work information, goal selection ability, planning ability, and skill in solving problems related to career development tasks. The reliability testing using Cronbach's Alpha technique resulted in the Alpha coefficient of 0.85 in magnitude. The data were analyzed statistically descriptively by using frequency and percentage tables, cross-tabulation analysis, and comparison between gender types and among students' batches of different years of entrance.

\section{RESULTS AND DISCUSSION}

From the comparison between the empirical mean score and the hypothetical one in the case of the research concerned here, it is known that the students' career maturity could initially be said to be high in level (72.4>62.5).

Based on the mean comparison, The classification used in the research referred to the model of classifying subjects into three categories according to Azwar (2003), namely, the low category with $\mathrm{X}<(\mathrm{M}-1 \mathrm{SD})$ as criterion, the medium category with $(\mathrm{M}-1 \mathrm{SD})<\mathrm{X}<(\mathrm{M}+1 \mathrm{SD})$ as criterion, and the high category with $(\mathrm{M}+1 \mathrm{SD})<\mathrm{X}$ as criterion. The following represents the career maturity profile obtained according to the above categorization.

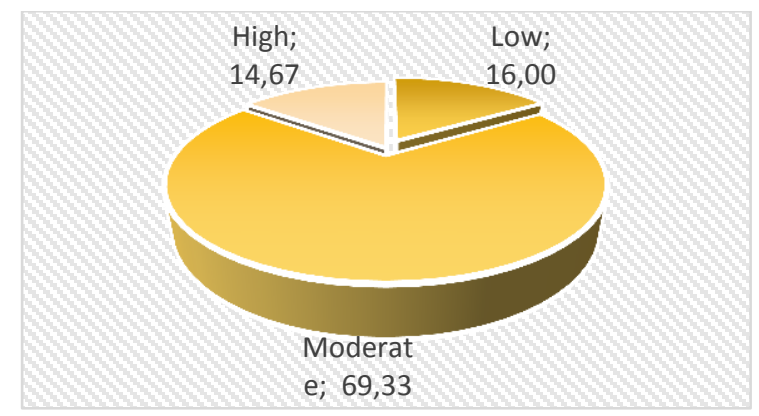

Fig. 1. The percentages of Guidancde and Counseling Student's Careet Maturity (with $\mathrm{n}=150$ )

The diagram in Figure 1 above shows that the degree of career maturity was normally distributed into 3 ordinal scales, namely, low (16\%), moderate $(69.3 \%)$, and high (14.7\%). At a glance, it looks as if the guidance and counseling students' career maturity profile could be said to be normal, small numbers of the students being categorized low and high while the great number were in the medium category.

TABLE II. GUIDANCE AND COUNSELING STUDENT'S CAREER MATURITY PROFILE ACCORDING TO SEX TYPE

\begin{tabular}{|c|c|c|c|c|c|}
\hline \multicolumn{2}{|c|}{ Normative Category } & \multicolumn{3}{|c|}{ Gender Type } & \multirow[t]{2}{*}{ Total } \\
\hline & & Norm & Male & Female & \\
\hline \multirow[t]{2}{*}{ Low } & Count & Low & 3 & 21.00 & 24 \\
\hline & $\begin{array}{l}\% \text { of } \\
\text { total }\end{array}$ & & 2 & 14.00 & $16 \%$ \\
\hline \multirow[t]{2}{*}{ Moderate } & Count & Moderate & 16 & 88.00 & 104 \\
\hline & $\begin{array}{l}\% \text { of } \\
\text { total }\end{array}$ & & 10.7 & 58.67 & $69.30 \%$ \\
\hline \multirow[t]{2}{*}{ High } & Count & High & 2 & 20.00 & 22 \\
\hline & $\begin{array}{l}\% \text { of } \\
\text { total }\end{array}$ & & 1.3 & 13.33 & $14.70 \%$ \\
\hline \multirow[t]{2}{*}{ Total } & Count & Total & 21 & 129.00 & 150 \\
\hline & $\begin{array}{l}\% \text { of } \\
\text { total }\end{array}$ & & 14 & 86.00 & $100 \%$ \\
\hline
\end{tabular}

The career maturity profile could also be viewed in terms of difference in gender type (See Table II). In the research, the female respondents were greater in percentage than the male ones. From the point of statistical measurement, the imbalance in number between the male subjects and the female ones 
could hinder the drawing of the conclusion concerning difference in career maturity as viewed from different gender types. Regardless of the difference in number, the data obtained from the descriptive statistical calculation show that the mean score for career maturity of the male group was 72.29 in magnitude while that of the female group was 72.44 in magnitude.

From the mean scores, it could be roughly seen that the two groups differing in gender type did not differ much in career maturity. Results of statistic testing also proved that there was no difference in that matter between the different gender types, since $\mathrm{F}=0.676$ with sig. $=0.412$. Even if the gender types were considered equal in variance, difference in career maturity between the two is not seen at all (since $\mathrm{t}=$ 0.92 with $\mathrm{df}=148$ and sig. $=0.927$ ).

This case of absence of difference in career maturity between men and women is actually relatively contradictory to the theoretical assumptions and empirical proof presented by preceding researchers. According to the review of the literature done by Sirohi (2013: 7), several instances of research on high school students indicate that there is difference in career maturity between men and women. There is a tendency there for the group of female students to be higher in score for career maturity compared to the group of male students. However, in some countries like India and a number among those in Africa, the tendency that occurs is on the contrary; there, men are far more mature compared to women. Those last-mentioned cases are caused more by cultural factors indicating women's dependence on men.

According to Bae (2017: 434), gender is an important personal predictor of career maturity [1]. However, he explained that there is little evidence that female students choose more approriate careers than male students do. More importantly, the influence of gender on career maturity has not been supported from a longitudinal perspective [1]. The difference between the male and female subjects was only in planning ability. The group of female students possessed planning ability which was far higher in level compared to that of the group of male students. In the research concerned, why the female students' group was in that way higher than the male students was not yet further explored.

TABLE III. CAREER MATURITy PROFILE ACCORDING TO YEAR OF ENTRANCE/STUDENT'S BATCH

\begin{tabular}{crrrr}
\hline \multirow{2}{*}{ Student Batch } & \multicolumn{3}{c}{ Normative Category } & \multirow{2}{*}{ Total } \\
\cline { 2 - 4 } & \multicolumn{1}{c}{ Low } & Medium & \multicolumn{1}{l}{ High } & \multicolumn{1}{c}{5} \\
\cline { 2 - 5 } 2013 & 5 & 40 & 5 & 50 \\
\hline \multirow{2}{*}{2014} & $3.3 \%$ & $26.7 \%$ & $3.3 \%$ & $33.3 \%$ \\
\cline { 2 - 5 } & $8.7 \%$ & $18.7 \%$ & $6.0 \%$ & $33.3 \%$ \\
\hline \multirow{2}{*}{2015} & 6 & 36 & 8 & 50 \\
\cline { 2 - 5 } & $4.0 \%$ & $24.0 \%$ & $5.3 \%$ & $33.3 \%$ \\
\hline \multirow{2}{*}{ Total } & 24 & 104 & 22 & 150 \\
\cline { 2 - 4 } & $16.0 \%$ & $69.3 \%$ & $14.7 \%$ & $100.0 \%$ \\
\hline
\end{tabular}

One of the interesting findings in the research is the absence of difference in career maturity among batches of students entering in different years. When inter-group comparisons of mean scores were done, they resulted in $\mathrm{F}=0.855$ with Sig. $=0.427$, indicating that the career maturity of each batch was not significantly different. From Table 5 above, it could be known that the greatest percentage of the students' career maturity was in the medium category for all students' batches involved, with the percentage being $26.7 \%$ for the 2013 batch, $18.7 \%$ for the 2014 batch, and $24.0 \%$ for the 2015 batch. That is a fact that refutes the researcher's team's assumption that the more senior the student, the better his or her career maturity, or, the senior student is better in career maturity compared to the junior student. What has been expected, however, is the fact indicating that, among the three batches of students gathered at the same time, the 2013 and 2014 batches of students of at least the moderate and high categories, being the senior batches, would be the highest in percentage.

The assumption is based on the logical thinking that senior students are already more complete in the number of subjects and classes taken and the amount of learning experience acquired compared to the students who are their juniors so that their career maturity profile is expected to be far better than that of those who are their juniors.

TABLE IV. DESCRIPTIVE STATISTICS OF GUIDANCE AND COUNSELING STUDENTS CAREER MATURITY

\begin{tabular}{|ll|r|r|r|r|r|}
\hline $\begin{array}{l}\text { Student } \\
\text { Batch }\end{array}$ & $\begin{array}{c}\text { Self- } \\
\text { Appraisal }\end{array}$ & $\begin{array}{c}\text { Work } \\
\text { Information }\end{array}$ & $\begin{array}{c}\text { Goal } \\
\text { Selection }\end{array}$ & Planning & $\begin{array}{c}\text { Problem } \\
\text { Solving }\end{array}$ \\
\hline 2013 & Mean & 14.2000 & 14.3600 & 15.5000 & 15.1200 & 13.9000 \\
Batch & 50 & 50 & 50 & 50 & 50 \\
& $\begin{array}{l}\text { Std. } \\
\text { Deviation }\end{array}$ & 1.60357 & 1.43939 & 1.47427 & 1.69802 & 1.68123 \\
\hline Mean & 13.9200 & 14.1000 & 14.9800 & 14.9600 & 13.3800 \\
Batch & N & 50 & 50 & 50 & 50 & 50 \\
& $\begin{array}{l}\text { Std. } \\
\text { Deviation }\end{array}$ & 2.78363 & 2.57341 & 1.64739 & 1.92682 & 2.09849 \\
\hline $\begin{array}{l}\text { Mean } \\
\text { Natc }\end{array}$ & 14.2800 & 14.3600 & 15.0200 & 14.9800 & 14.2000 \\
Natch & 50 & 50 & 50 & 50 & 50 \\
& $\begin{array}{l}\text { Std. } \\
\text { Deviation }\end{array}$ & 2.14799 & 1.82678 & 1.57130 & 1.81254 & 1.94831 \\
\hline Total & $\begin{array}{l}\text { Mean } \\
\text { N }\end{array}$ & 14.1333 & 14.2733 & 15.1667 & 15.0200 & 13.8267 \\
& $\begin{array}{l}\text { Std. } \\
\text { Deviation }\end{array}$ & 2.22151 & 1.99293 & 1.57334 & 1.80406 & 1.93431 \\
\hline
\end{tabular}

As seen from the mean scores concerned (See Table 4), the variables in career maturity show no striking inter-batch difference. At a glance, it could be expressed that its various aspects, namely, self-appraisal, work information, goal selection, planning, and problem solving, seem to show little inter-batch difference.

The obvious difference in mean score among the three batches of students was only for the aspect of goal selection 
ability. According to Table 5, contrary to expectation, the 2015 batch, as the youngest among the three batches concerned, was relatively equal in mean score to another batch which was more senior, namely, the 2013 batch. Whether the difference was insignificant or not, the relatively equal mean score lets rise the idea that the said younger batch was higher in level of that ability than its seniors. However, similar with the study conducted by Cheng et. al (2016: 1), there was no difference in career maturity based on age, a finding that conflicts with the findings of a previous study conducted by Wendy Patton (Cheng et. al., 2016: 1).

\section{CONCLUSION}

With the above data exposition as basis, several points that could be drawn as conclusion are as follows: 1). the career maturity of students in the Guidance and Counseling Study Program at Yogyakarta State University, is categorized as moderate in level (with $\mathrm{M}=72.42$ ), with $69.3 \%$ of the students being in the moderate category, 2). that very great percentage being in "the moderate category" suggests a group which is quite vulnerable to experiencing instability in the matter of career maturity if not intervened/facilitated well, and 3). There is no significant difference in career maturity among batches of students different in year of entrance into the university (since $\mathrm{F}=0.855$ with Sig. $=0.427$ ). As findings, they deserve to become matters of common concern because the ideal picture of the increasingly higher level and attainment of achievement of individuals (who are, in this case, guidance and counseling students) turns out not to guarantee abilities and characteristics that are also far better.

\section{REFERENCES}

[1] S. Bae, "An analysis of career maturity among Korean youth using latent growth modelling”, in School Psychology International, Vol. 38 No. 4, pp 434-449, 2017

[2] D. Brown \& L. Brooks, Career counseling techniques. Boston, USA: Allyn and Bacon, 2007

[3] C. Cheng, L. Yang, Y. Chen, H. Zou, Y. Su \& X. Fan, "Attributions, future time perspective and career maturity in nursing undergraduates: correlational study design", in BMC Medical Education, Vol. 16, p 26, 2016

[4] J.H. Greenhaus, \& G. A. Callanan, Encyclopedia of career development, Sage Publication, London, 2006.

[5] T.L. Grier-Reed, N.R. Skaar, \& J.L Conbel-Ziebell, "Constructivitst career development as a paradigm of empowerment for at-risk culturally diverse college students", in Journal of Career Development, Vol. 35, pp 290-305, 2009

[6] R.S. Sharf, Applying career development theory to counseling, California, USA: Brooks/Cole Publishing, 1992

[7] V. Sirohi, "Vocational guidance and career maturity among secondary school students; an Indian experience", in Annual International Interdisciplinary Conference (AIIC), 24-26 April, Azores, Portugal, 2013

[8] A B Spear and S M Strurdevant, "Adolescent psychosocial development", in American Diet Association, journal of the American Dietic Association, suppl. Adolescent Nutrition: A Springboard for Health, Vol. 102 No. 3, 2002

[9] A S Ellen and W B David, "Mapping adult life changes: A conceptual framwork for Organizing Adult development theory", in Journal of Counseling and Develompent, Vol 60 Issue 8, pp 576-582, 1982
[10] K B M Noor, "Case Study: A Strategic Research Methodology", in American Journal of Applied Sciences, Vol 5 No. 11, pp 1602-1604, 2008

[11] R Matthias and V W Fred, "The viability of career maturity theory: A developmental-contextual perspective", in The Career Development Quarterly, Vol 47 Issue 1, pp 6-15, 1998

[12] H E Erin, L T L Frederick, and O H Samuel, "Cultural Relativity in the Conceptual of Career Maturity", in Journal of Vocational Behavior, Vol 58 Issue 1, pp 36-52, 2001

[13] E B Nancy and M T Karen, "Applications of self-efficacy theory to the understanding and treatment of career indecision", in Journal of Vocational Behavior, Vol. 22 Issue 1, pp 63-81, 1983

[14] S L Mark, "Career Maturity: The construct and its measurement", in The Career Development Quarterly, Vol. 32 Issue 4, pp 22-31, 1984

[15] C Sumi, H Brian, E L Matthew, P Mark, "A longitudinal study of the developmental trajectories of parental attachment and career maturity of South Korean adolescents", in The Career Development Quarterly, Vol. 60 Issue 2, pp 163-177, 2012. 